\title{
A 3-year prospective randomized controlled clinical trial of group care in type 1 diabetes
}

\author{
M. Trento ${ }^{a, *}$, P. Passera ${ }^{a}$, E. Borgo ${ }^{a}$, M. Tomalino ${ }^{a}$, M. Bajardi $^{a}$,

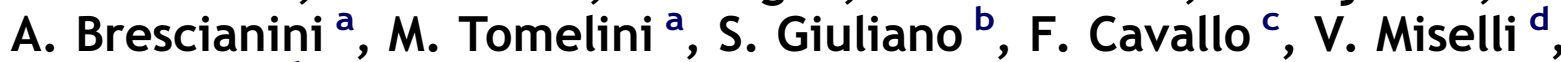 \\ P. Bondonio ${ }^{b}$, M. Porta ${ }^{a}$
}

${ }^{a}$ Department of Internal Medicine, University of Turin, Corso AM Dogliotti 14, I-10126 Torino, Italy

${ }^{\mathrm{b}}$ Department of Economics, University of Turin, Italy

c Department of Public Health and Microbiology, University of Turin, Italy

d Diabetes Unit, Scandiano Hospital, Italy

Received 22 July 2004; received in revised form 30 November 2004; accepted 16 December 2004

\section{KEYWORDS}

Type 1 diabetes; Psychosocial support; Patient education; Quality of life; Health behaviours

\begin{abstract}
Summary Background and aims: We showed that continuing education can be embedded into routine diabetes care by seeing patients in small groups rather than individually. Group care was cost-effective in improving quality of life, knowledge of diabetes, health behaviours and clinical outcomes in people with type 2 diabetes. The aim of this study was to verify if group care can also be applied to type 1 diabetes.

Methods and results: Randomized, controlled clinical trial comparing 31 patients managed by group care with 31 managed by traditional one-to-one care. A syllabus was built and later remodulated with the patients in a series of focus-group meetings. The primary end-point was changes in quality of life. Secondary endpoints were: knowledge of diabetes, health behaviours, HbA1c and circulating lipids. Differential costs to the Italian National Health System and to the patients were also calculated.

After 3 years, quality of life improved among patients on group care, along with knowledge and health behaviours $(p<0.001$, all). Knowledge added its effects to those of group care by independently influencing behaviours $(p=0.004)$ while quality of life changed independently of either $(p<0.001)$. Among controls, quality of life worsened $(p<0.001)$ whereas knowledge and behaviours remained unchanged. HDL cholesterol increased among patients on group care $(p=0.027)$ and total cholesterol decreased in the controls $(p<0.05)$. HbA1c
\end{abstract}

Abbreviations: CdR, health behaviours (Condotte di Riferimento); DQOL, diabetes quality of life; GISED, Italian Study Group on Diabetes Education; INHS, Italian National Health System.

* Corresponding author. Tel.: + 39011 6632354; fax: + 390116634751.

E-mail address: marina.trento@unito.it (M. Trento). 
decreased, though not significantly, in both. Direct costs for group and one-to-one care were $€ 933.19$ and $€ 697.10$ per patient, respectively, giving a costeffectiveness ratio of $€ 19.42$ spent per point gained in the quality of life scale. Conclusions: Group care is applicable and also cost-effective in type 1 diabetes. It improves quality of life, knowledge and behaviours. Future programme adjustments should strive to impact more on metabolic control.

(c) 2005 Elsevier B.V. All rights reserved.

\section{Introduction}

Type 1 diabetes (T1DM) is a chronic illness that requires continuing professional care combined with patient self-care to prevent or delay acute and long-term complications [1-5]. The primary goals of treatment are to maintain blood glucose levels and quality of life as close as possible to those of non-diabetic people [6]. Intensified insulin therapy improves metabolic control and reduces the incidence of complications $[7,8]$ but, to fully benefit from it, patients need knowledge and skills that enable them to make informed choices to facilitate appropriate behavioural changes $[1,9,10]$. Such benefits can only be achieved if patients are offered structured and comprehensive education integrated in diabetes care. Indeed, patient-centred approaches have demonstrated positive outcomes for health behaviours and metabolic control $[11,12]$.

Usually, patient education is offered as an adjunct to clinical care, within routine one-to-one visits or as self-contained structured courses for individuals or groups $[4,5,13,14]$. This requires allocation of additional time and resources that are scarce in most clinics. We have shown that continuing education can be embedded into the routine care of non-insulin-treated type 2 diabetes (T2DM) if patients are regularly seen in small groups rather than individually. Group care was found to be a feasible, cost-effective approach to improve quality of life, knowledge of diabetes and health behaviours while achieving sustained weight reduction, stabilization of $\mathrm{HbA1C}$ and increased $\mathrm{HDL}$ cholesterol over 5 years [15-17].

This study was aimed at verifying if group care can also be applied to the routine care of T1DM. In particular, we tested if, also in T1DM, group care would improve patients' quality of life, knowledge of diabetes, health behaviours and metabolic control.

\section{Methods}

Sixty-two people with T1DM were randomly selected by random table numbers by one member of the team from the patient population in our clinic. Inclusion criteria were: onset before age 30 and insulin treatment started within 1 year of diagnosis; age $<70$ and at least 1 year previous attendance in our clinic. All patients were on 4-daily insulin injections and practiced self-monitoring of blood glucose. Seven patients on group care and 7 controls were on LisPro insulin. None was on hypolipidaemic agents at the time of study. None refused to participate and all gave their informed consent to the study, which conformed with the principles of the Helsinki Declaration. After randomization by random table numbers, 31 patients were assigned to 5 groups of 6-7 patients each, while 31 control subjects continued with traditional individual consultations. Their baseline characteristics are listed in Table 1. In spite of randomization, control patients had different schooling levels $(p<0.05)$ and higher HbA1c levels at baseline $(p=0.015)$.

\section{Education programme}

Four focus groups [18-20] were run with 5/6 patients each, not necessarily including those who participated in the study, to explore their expectations, needs, knowledge and beliefs on diabetes [21]. These sessions were audiotaped, transcribed verbatim and analysed to establish the educational goals [18]. The patients wished to learn more on: slow-, intermediate-, fast-, and very fast-acting insulins; insulin injection techniques, areas and rotation; hypoglycaemia and hyperglycaemia; what to do during intercurrent illnesses; glycated haemoglobin, fructosamine and glycosuria; complications: blindness and kidney failure; what to do in the occasion of regular check-ups for driving licence renewal and occupational medicine; nutrition and physical exercise. A 9-session programme was developed according to a systemic education approach [22] to address these topics.

After these 9 sessions, the programme was reassessed in a second round of focus groups, this time involving all the patients who had received group care. Expectations and requests were again collected and re-analysed, leading to a redefinition 
Table 1 Clinical data of patients at baseline

\begin{tabular}{|c|c|c|c|}
\hline & Group care & Controls & \\
\hline $\begin{array}{l}\text { No. } \\
\text { Sex }\end{array}$ & 31 & 31 & \\
\hline M & $19(61.3 \%)$ & $18(58.1 \%)$ & N.S. \\
\hline $\mathrm{F}$ & $12(38.7 \%)$ & $13(41.9 \%)$ & \\
\hline Age (median and interquartile range) & $27(23-33)$ & $31(25-43)$ & N.S. \\
\hline $\begin{array}{l}\text { Schooling } \\
\text { P } \\
\text { M } \\
\text { H } \\
\text { U }\end{array}$ & $\begin{aligned} 2 & (6.5 \%) \\
3 & (9.7 \%) \\
25 & (80.6 \%) \\
1 & (3.2 \%)\end{aligned}$ & 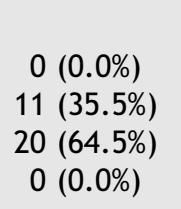 & $p<0.05$ \\
\hline $\begin{array}{l}\text { Occupation }^{\mathrm{b}} \\
\text { H } \\
\mathrm{R} \\
\text { W } \\
\text { B } \\
\text { S } \\
\text { O }\end{array}$ & $\begin{array}{c}0(0.0 \%) \\
2(6.5 \%) \\
4(12.9 \%) \\
1(3.2 \%) \\
11(35.5 \%) \\
13(41.9 \%)\end{array}$ & $\begin{aligned} 2 & (6.4 \%) \\
3 & (9.7 \%) \\
4 & (12.8 \%) \\
1 & (3.2 \%) \\
6 & (19.5 \%) \\
15 & (48.4 \%)\end{aligned}$ & N.S. \\
\hline Duration of diabetes (median and interquartile range) & $16(13-19)$ & $15(12-19)$ & N.S. \\
\hline Family history of DM & $10(32.3 \%)$ & $14(45.2 \%)$ & N.S. \\
\hline $\begin{array}{l}\text { Smoking } \\
\text { Current } \\
\text { Never } \\
\text { Stopped }\end{array}$ & $\begin{aligned} 4 & (12.9 \%) \\
26 & (83.9 \%) \\
1 & (3.2 \%)\end{aligned}$ & $\begin{array}{l}11(35.5 \%) \\
18(58.1 \%) \\
2(6.4 \%)\end{array}$ & N.S. \\
\hline $\begin{array}{l}\text { Previous structured education } \\
\text { Yes } \\
\text { No }\end{array}$ & $\begin{array}{c}30(96.8 \%) \\
1(3.2 \%)\end{array}$ & $\begin{array}{r}0(0.0 \%) \\
31(100 \%)\end{array}$ & N.S. \\
\hline $\begin{array}{l}\text { Hypertensive } \\
\text { Yes } \\
\text { No }\end{array}$ & $\begin{array}{r}3(10.3 \%) \\
26(89.7 \%)\end{array}$ & $\begin{array}{r}7(25 \%) \\
21(75 \%)\end{array}$ & N.S. \\
\hline
\end{tabular}

${ }^{a} \mathrm{P}$, primary school; $M$, middle school; $\mathrm{H}$, high school; $\mathrm{U}$, university degree.

${ }^{b} \mathrm{H}$, housewife; $\mathrm{R}$, retired; $\mathrm{W}$, white collar; $\mathrm{B}$, blue collar; $\mathrm{S}$, student, $\mathrm{O}$, other.

of educational and health objectives [21]. The new curriculum designed with the patients included: differences between type 1 and type 2 diabetes; principles of nutrition, classification of nutrients, composition of food and food exchanges: personal habits and day-to-day management; how to embed eating patterns into daily life, as tastes and habits evolve over time; physical exercise: adaptation of insulin dosage and daily activity; hypoglycaemia and hyperglycaemia: why do they occur, how to recognize and manage them, how to inform relatives and friends; areas of insulin injection and their rotation; retinopathy, neuropathy, microalbuminuria and nephropathy: self-care, when and how to screen; hypertension and cardio-vascular aspects. The patients also requested that insulin, glycated haemoglobin and day-to-day problems be discussed whenever felt necessary. This patientcentred approach [23] allowed us to re-design a new 9-visit programme. Six more visits were delivered over the reminder of the 36 months' observation reported in this paper, for a total of 15 group care sessions.

\section{Procedure for group care}

As is routine practice in our clinic, samples for blood glucose, $\mathrm{HbA1C}$ and urine analysis, plus other annual tests when applicable, were taken a few days beforehand. Results were transcribed and case notes checked by the doctor shortly before group consultations.

Group visits were held every $2-3$ months by a doctor (PP) and a psychopaedagogist (MTr), who acted as facilitators according to the methodological principles of adult learning [24,25]. Sessions were centred on hands-on activities, group work, 
problem-solving exercises, real life simulations and role playing, as well as group discussions concerned with motivational aspects, acceptance of diabetes, psychosocial problems and coping strategies. In order to induce positive group dynamics, patients were helped to identify and share their problems and successes with the other members and encouraged to report on their personal experience, if they wished to [22-23]. Sessions were planned to last $40-50 \mathrm{~min}$ and were followed by brief individual consultations with the same doctor, to comment on laboratory results, the previous group session, and yearly check-up or emerging problems, if any.

Control patients continued to follow habitual 2-3 monthly one-to-one consultations in the diabetes clinic. They received individual education sessions from the same psychopaedagogist involved in group care, with special reference to proper eating habits, home monitoring of blood glucose, insulin administration and dose adjustments, and preventing complications. Their knowledge of diabetes was checked annually, when screening for complications, and educational reinforcement offered accordingly. Control patients were also offered 15 individual visits over the 3-year observation period.

Because of its approach, this study could not be run as a double-blind trial. To minimize performance bias, health operators were blinded to which patients in the general diabetes clinic served as controls. Results were adjusted for schooling on multivariate analysis, to account for possible selection bias resulting from differences in schooling at baseline. Minimal dropout rate in both treatment groups suggests negligible attrition bias. Finally, outcomes were measured blindly with respect to treatment group.

\section{Evaluation of results}

Body weight, fasting blood sugar (glucose-oxidase) and HbA1c (HPLC) were measured at each visit. Total and HDL cholesterol, triglyceride and microalbuminuria/creatininuria ratio, were measured yearly during routine screenings for complications. Hypoglycaemic episodes were assessed retrospectively on the clinic case notes. Severe hypoglycaemia was defined as requiring third-party help, i.e., glucagons injection, i.v. glucose and/or hospital admission.

Three questionnaires were administered at baseline and after 3 years to measure:

(a) Quality of life, using the original version of the DQOL questionnaire [6] translated into Italian and revalidated [26]. This questionnaire explores four primary scales: satisfaction, impact, diabetes worry, and social/vocational worry with 46 core items. Each item scores between 5 (very dissatisfied) and 1 (very satisfied). Hence, the total score ranges between 46 (higher quality of life) and 230 (lower quality of life).

(b) Knowledge of T1DM, using a 57-item questionnaire developed and validated by the Education Study Group of the Italian Society for Diabetes (GISED) [27]. Correct answers scored 1 point and wrong answers scored 0.

(c) Health behaviours ("Condotte di Riferimento"), with a purpose-built 30-item questionnaire for T1DM (CdR-T1DM) that explores simulated problem-solving ability. Questions posed hypothetical situations using the "What would you do if ..." format to test ability to identify underlying health problems and react correctly. The situations proposed involved coping with hypoglycaemia, glucagon injections, adapting insulin dosages to physical activity and food ingestion, intercurrent disease, organizing holidays, informing relatives and friends. Correct answers scored 1 point and wrong ones scored 0 . The questionnaire was checked for internal consistency, by Cronbach's alpha coefficient [28], and for internal validity by cluster analysis [29].

\section{Economic analysis}

Economic analysis was carried out from a quasisocietal point of view with a cost-utility approach, by calculating additional costs associated with additional results of group care compared with one-to-one visits.

Differential costs were calculated in Euros $(€)$ from the perspectives of both the Italian National Health System (INHS) and the patients. All procedures relevant to group and individual care were directly timed and the relevant salaries of personnel involved calculated, assigning specific roles for different group care sessions to a doctor, nurse, dietician or psychopaedagogist. Based upon average salaries, costs to the INHS were estimated at $€$ $0.85 / \mathrm{min}$ for physicians, $€ 0.32 / \mathrm{min}$ for registered nurses, $€ 0.33 / \mathrm{min}$ for dieticians, and $€ 0.72 / \mathrm{min}$ for a psychopaedagogist. Costs of insulin, diagnostic materials and tests, and personnel time to update clinical records were not included, because they did not differ between group care and controls. Differential costs of rooms and materials were negligible, hence ignored. Direct costs borne 
by the patients included transportation and costopportunity of time spent in clinic, as obtained from specific questionnaires administered to 27 patients on group care and 26 controls. The questionnaires also included 2 items in which patients were asked to indicate on 1-5 Likert scales: (1) their level of perceived satisfaction and (2) their opinion on the usefulness of the treatment received. Patients on group care were also asked if they would rather have individual visits instead.

As previously done with T2DM [15-17], quality of life was chosen as a non-clinical end-point representative of the patients' perceived well being.

\section{Statistical methods}

Unless otherwise specified, results are expressed as either mean \pm 1 standard deviation, if the variable is approximately normally distributed, or median and interquartile range (25th-75th) if skewed or non-continuous. The Statistical Package for Social Sciences (SPSS Inc., Chicago, IL) was used for calculations and to check the validity of questionnaires.

Differences between baseline and year 3 values within treatment groups are expressed as mean and $95 \% \mathrm{Cl}$. Changes in clinical, cognitive and behavioural variables from baseline to year 3 between the two treatment groups were tested by an analysis of covariance approach, adjusted for baseline differences in the two groups.

A multivariate regression model was fitted, using as dependent variable the calculated increase/decrease from baseline to year 3 for each cognitive and behavioural variable (DQOL, GISED,
(dR) and for each clinical variable. Group care (coded 0/1), baseline values of the dependent variables and of the other cognitive or behavioural variables plus baseline values of $\mathrm{HbA} 1 \mathrm{c}$, age, duration of diabetes (coded in years) and schooling (coded in a 2-level ordinal scale and introduced in the model as dummy variable) were used as independent variables.

\section{Results}

After 3 years, 1 patient on group care and 1 control moved to other cities because of work commitments and were lost to follow-up. Two more control patients declined to participate in the final visit and to fill in the questionnaires. In total, data from 30 patients on group care and 28 controls were available for final analysis. Patients on group care missed only 20 out of $465(31 \times 15)$ scheduled appointments $(4.3 \%)$, whereas controls missed 79 (16.7\%), $p<0.001$.

Univariate analysis showed that quality of life, knowledge of diabetes and health behaviours improved in the patients followed by group care $(p<0.001$, all). Among control patients, in contrast, quality of life worsened $(p<0.001)$ whereas knowledge and behaviours remained unchanged (Table 2). Cronbach's coefficient for the CdRT1DM questionnaire was 0.59 at baseline and 0.64 three years later.

Multivariate analysis showed that the effect of group care on quality of life, knowledge and health behaviours was independent of age, duration of diabetes or schooling. Being treated by group care improved quality of life independently of knowledge and behaviours $(p<0,001)$. Knowledge, in turn, appeared to influence behaviours

Table 2 Knowledge of diabetes, health behaviours and quality of life at baseline and year 3 in patients on group care $(n=30)$ and controls on individual care $(n=28)$

\begin{tabular}{|c|c|c|c|c|c|}
\hline & & $\begin{array}{l}\text { Baseline } \\
\text { (mean } \pm S D)\end{array}$ & $\begin{array}{l}3 \text { years } \\
(\text { mean } \pm S D)\end{array}$ & $\begin{array}{l}\text { Increase/decrease } \\
\text { (mean and } 95 \% \mathrm{CI} \text { ) }\end{array}$ & $\begin{array}{l}\text { Difference } \\
\text { between group } \\
\text { care and } \\
\text { controls } \\
\text { (significance) }\end{array}$ \\
\hline $\begin{array}{l}\text { Knowledge } \\
\text { of diabetes } \\
\text { (GISED score) }\end{array}$ & $\begin{array}{l}\text { Group care } \\
\text { Controls }\end{array}$ & $\begin{array}{l}44.34 \pm 6.97 \\
43.10 \pm 6.28\end{array}$ & $\begin{array}{l}47.45 \pm 6.03 \\
43.34 \pm 6.18\end{array}$ & $\begin{array}{l}3.10(1.56 \text { to } 4.65)^{* *} \\
0.24(-0.32 \text { to } 0.80)\end{array}$ & $p<0.01$ \\
\hline $\begin{array}{l}\text { Health behaviours } \\
\text { (CdR-T1DM score) }\end{array}$ & $\begin{array}{l}\text { Group care } \\
\text { Controls }\end{array}$ & $\begin{array}{l}21.48 \pm 3.18 \\
22.38 \pm 3.51\end{array}$ & $\begin{array}{l}25.28 \pm 2.66 \\
22.28 \pm 3.35\end{array}$ & $\begin{array}{r}3.79(2.61 \text { to } 4.98)^{* *} \\
-0.10(-0.41 \text { to } 0.21)\end{array}$ & $p<0.001$ \\
\hline $\begin{array}{l}\text { Quality of life } \\
\text { (DQOL score) }\end{array}$ & $\begin{array}{l}\text { Group care } \\
\text { Controls }\end{array}$ & $\begin{array}{l}79.37 \pm 13.93 \\
80.72 \pm 11.52\end{array}$ & $\begin{array}{l}70.55 \pm 12.20 \\
84.06 \pm 11.35\end{array}$ & $\begin{array}{l}-8.82(-12.51 \text { to }-5.14)^{* *} \\
3.34(2.38 \text { to } 430)^{* *}\end{array}$ & $p<0.001$ \\
\hline
\end{tabular}

${ }^{* *} p<0.001$. 
Table 3 Biochemical and clinical variables at baseline and year 3 in patients on group care $(n=30)$ and controls on individual care $(n=28)$

\begin{tabular}{|c|c|c|c|c|c|}
\hline & & $\begin{array}{l}\text { Baseline } \\
\text { (mean } \pm \text { SD) }\end{array}$ & $\begin{array}{l}3 \text { years } \\
(\text { mean } \pm S D)\end{array}$ & $\begin{array}{l}\text { Increase/decrease } \\
\text { (mean and } 95 \% \mathrm{Cl} \text { ) }\end{array}$ & $\begin{array}{l}\text { Difference } \\
\text { group } \\
\text { care-controls } \\
\text { (significance) }\end{array}$ \\
\hline $\begin{array}{l}\text { Body } \\
\text { weight }(\mathrm{kg})\end{array}$ & $\begin{array}{l}\text { Group } \\
\text { care } \\
\text { Controls }\end{array}$ & $\begin{array}{l}71.91 \pm 10.28 \\
70.35 \pm 10.97\end{array}$ & $\begin{array}{l}72.08 \pm 10.42 \\
70.47 \pm 13.45\end{array}$ & $\begin{array}{l}0.17(1.48 \text { to }-1.14) \\
0.12(-2.59 \text { to } 2.84)\end{array}$ & N.S. \\
\hline $\begin{array}{l}\text { Body mass } \\
\text { index }\left(\mathrm{kg} / \mathrm{m}^{2}\right)\end{array}$ & $\begin{array}{l}\text { Group } \\
\text { care } \\
\text { Controls }\end{array}$ & $\begin{array}{l}24.70 \pm 3.37 \\
25.04 \pm 3.78\end{array}$ & $\begin{array}{l}24.74 \pm 3.26 \\
25.09 \pm 4.04\end{array}$ & $\begin{array}{l}0.04(-0.42 \text { to } 0.50) \\
0.05(-0.91 \text { to } 1.01)\end{array}$ & N.S. \\
\hline $\begin{array}{l}\text { Fasting blood } \\
\text { glucose (mmol/L) }\end{array}$ & $\begin{array}{l}\text { Group } \\
\text { care } \\
\text { Controls }\end{array}$ & $\begin{array}{r}9.61 \pm 6.14 \\
12.25 \pm 5.35\end{array}$ & $\begin{array}{r}9.48 \pm 4.78 \\
11.18 \pm 5.45\end{array}$ & $\begin{array}{l}-0.13(-3.87 \text { to } 3.60) \\
-1.06(-3.69 \text { to } 1.56)\end{array}$ & N.S. \\
\hline $\begin{array}{l}\mathrm{HbA}_{1 \mathrm{c}} \text { (percentage } \\
\text { of total haemoglobin) }\end{array}$ & $\begin{array}{l}\text { Group } \\
\text { care } \\
\text { Controls }\end{array}$ & $\begin{array}{l}8.26 \pm 0.15 \\
9.20 \pm 1.64\end{array}$ & $\begin{array}{l}7.88 \pm 0.20 \\
8.79 \pm 1.38\end{array}$ & $\begin{array}{l}-0.38(-0.83 \text { to } 0.07) \\
-0.40(-0.85 \text { to } 0.04)\end{array}$ & N.S. \\
\hline $\begin{array}{l}\text { Insulin dosage } \\
\text { (Units/kg body weight) }\end{array}$ & $\begin{array}{l}\text { Group } \\
\text { care } \\
\text { Controls }\end{array}$ & $\begin{array}{l}0.75 \pm 0.15 \\
0.68 \pm 0.27\end{array}$ & $\begin{array}{l}0.75 \pm 0.20 \\
0.72 \pm 0.27\end{array}$ & $\begin{array}{l}0.003(-0.052 \text { to } 0.059) \\
0.037(-0.034 \text { to } 0.11)\end{array}$ & N.S. \\
\hline $\begin{array}{l}\text { Total cholesterol } \\
\text { (mmol/L) }\end{array}$ & $\begin{array}{l}\text { Group } \\
\text { care } \\
\text { Controls }\end{array}$ & $\begin{array}{l}4.89 \pm 0.96 \\
5.08 \pm 1.32\end{array}$ & $\begin{array}{l}4.78 \pm 0.98 \\
4.65 \pm 1.16\end{array}$ & $\begin{array}{l}-0.09(-0.31 \text { to } 0.13) \\
-0.42(-0.76 \text { to }-0.09)^{*}\end{array}$ & N.S. \\
\hline $\begin{array}{l}\text { HDL cholesterol } \\
(\mathrm{mmol} / \mathrm{L})\end{array}$ & $\begin{array}{l}\text { Group } \\
\text { care } \\
\text { Controls }\end{array}$ & $\begin{array}{l}1.67 \pm 0.42 \\
1.62 \pm 0.39\end{array}$ & $\begin{array}{l}1.79 \pm 0.44 \\
1.64 \pm 0.35\end{array}$ & $\begin{array}{l}0.11(0.01 \text { to } 0.22)^{*} \\
0.02(-0.10 \text { to } 0.14)\end{array}$ & N.S. \\
\hline $\begin{array}{r}\text { Triglyceride } \\
\text { (mmol/L) }\end{array}$ & $\begin{array}{l}\text { Group } \\
\text { care } \\
\text { Controls }\end{array}$ & $\begin{array}{l}0.73 \pm 0.23 \\
1.16 \pm 0.57\end{array}$ & $\begin{array}{l}0.81 \pm 0.30 \\
1.13 \pm 0.61\end{array}$ & $\begin{array}{l}0.08(-0.04 \text { to } 0.21) \\
-0.03(-0.30 \text { to } 0.24)\end{array}$ & N.S. \\
\hline Albuminuria/creatininuria ${ }^{a}$ & $\begin{array}{l}\text { Group } \\
\text { care } \\
\text { Controls }\end{array}$ & $\begin{array}{l}0.93(0.53-2.5) \\
1.0(0.56-2.5)\end{array}$ & $\begin{array}{l}1.1(0.52-2.13) \\
0.91(0.27-2.18)\end{array}$ & - & N.S. \\
\hline $\begin{array}{l}\text { Foot ulcers } \\
\text { (never/past/active) }\end{array}$ & $\begin{array}{l}\text { Group } \\
\text { care } \\
\text { Controls }\end{array}$ & $\begin{array}{l}30 / 0 / 0 \\
28 / 0 / 0\end{array}$ & $\begin{array}{l}29 / 1 / 0 \\
25 / 3 / 0\end{array}$ & $\begin{array}{l}- \\
-\end{array}$ & N.S. \\
\hline
\end{tabular}

${ }^{*} p<0.05 ;{ }^{* *} p<0.001$.

${ }^{a}$ Due to the non-normal distribution of the data, median and interquartile range (25th-75th) are reported for this variable. For the same reason the Wilcoxon signed rank test has been used to test the difference between baseline and 3 year value.

independently of the effect of group care $(p=0.004)$, summing its effects to those of group care.

HbA1c decreased, though not significantly so, in both group and control patients. Total cholesterol decreased in the controls $(p<0.05)$, while HDL cholesterol increased in the patients on group care $(p=0.027)$. There were no significant modifications in the other clinical variables monitored (Table 3). Only 1 patient on group care had a glucagon-requiring episode of hypoglycaemia and 4 more had one episode each that did not require third-party assistance. Among controls,
3 patients had 3, 2 and 1 episodes, respectively, and 1 required admission for ketoacidosis.

Group care sessions had an average duration of $45.8 \pm 4.6 \mathrm{~min}$, followed by $7.5 \pm 0.9 \mathrm{~min}$ for each individual consultation. One-to-one control visits required $19.0 \pm 1.6 \mathrm{~min}$. Overall, over 3 years, INHS costs were $€ 177.79$ per patient in group sessions $+€ 93.45$ for the following individual meeting with the doctor, totalling $€ 271.24$. Control visits cost the INHS $€ 120.15$ per patient. Patient transportation costs were $€ 526.95$ for either option. Patients estimated the costopportunity of their time in clinic at $€ 135.00$ 
and $€ 49.50$, totalling $€ 661.95$ and 576.45 for group and one-to-one care, respectively.

In total, direct costs per patient for group and one-to-one care were $€ 933.19$ and $€ 697.10$, respectively. The $€ 236.09$ difference, divided by the 12.16 differential DQOL score between group and individual care, gives a cost-utility ratio of $€ 19.42$ spent over 3 years for each point gained in the quality of life scale. Taking into account actual attendance rates, costs for group care changed to $€ 907.88$ and those of one-to-one visits decreased to $€ 574.31$ per patient actually attending appointments. Assuming that INHS resources saved were used efficiently for other purposes, the gap would widen to $€ 333.57$, or $€ 27.43$ per point gained in the quality of life scale. In another sensitivity analysis, using a smaller team composed of well-trained nurses and dieticians reduced to $€ 12.83$ the extra cost spent per point gained in the quality of life scale.

There was no difference in the level of perceived satisfaction for treatment between patients on group care $(2.78 \pm 0.58)$ and controls $(2.96 \pm 0.66)$, but the former assigned a higher score to the usefulness of group care $(1.07 \pm 0.27)$ than those on individual care $(2.00 \pm 0.80)$, $p<0.0001$. One patient declared he would prefer individual visits because group care clashed with his timetable, whereas the other 26 interviewed opted to continue group care, because they felt it improved their knowledge and allowed them to share their problems with similarly affected people.

\section{Discussion}

This paper confirms that group care is a feasible and cost-effective approach to delivering continuing education within routine care to patients with T1DM, similarly to what we previously showed in patients with non-insulin-treated T2DM [17-19]. Also in T1DM, group care improved quality of life, knowledge of diabetes and health behaviours with acceptable additional costs, although the effects on metabolic control were more evident on HDL cholesterol than on HbA1c levels (Tables 2 and 3).

Differently from our experience with T2DM, T1DM patients were involved from the start in developing the education programme through focus groups [18] held to define the topics to be covered and their relative emphasis. Interestingly, when focus groups were repeated after one full cycle of sessions, the patients' choices and interests $[30,31]$ had changed, suggesting that a major shift had occurred from a rather "academic" approach to a vision based upon the patients' own expectations, needs and goals [21]. Collaborative alliance, mutual decision making, sustained partnerships and shared responsibilities are the tools that describe this patient-centred approach, implying continuous resetting of individualized goals and expectations [23]. These observations confirm that formative evaluation can be used to design education programmes to meet patients' perceived needs [25].

The results suggest that diabetic adults acquire new knowledge and behaviours, independently of schooling or age, if exposed to procedures and settings specifically tailored to their needs and characteristics. Knowledge appeared to influence behaviours independently of the effect of group care, suggesting that our approach was not only able to deliver new notions but also to further motivate patients to put them into practice. In contrast, patients followed by the traditional oneto-one approach did not modify their knowledge or ability to solve simulated daily problems. Selected interventions that improve patients' adherence can be educational, affective or behavioural [32]. Education may take the form of individual instruction or group classes, it might be provided in writing or through media like videotapes, computers or access to special internet sites, but in any event the key is providing a simple, clear message, hopefully tailored to the needs of the individual, and verifying that the message has been understood [33].

Quality of life improved directly as a result of group care, independently of knowledge, health behaviours, age, duration of diabetes, schooling or clinical variables. Quality of life is influenced by multifaceted factors, which are not necessarily those involved in day-to-day self-management $[31,34]$, and is linked to self-perception and other psychosocial factors including health-related beliefs, social support, coping style and personality type, either directly or because they help in buffering the negative effects of diabetes or its management. Advantages of group over individual care include emotional support from peers and ability to use the experiences of others as a model. Being part of a group, being understood by others and understanding them, and being able to give and receive help strengthens the sense of belonging and enhances emotional well being. Previous clinical and educational intervention studies suggest that improving patients' health status and perceived ability to control their disease results in better quality of life [34]. In contrast, quality of life was reported to decrease with increasing duration of diabetes [35,36], as it did in our control group, though not all authors confirm this finding [37]. 
Group care aimed at modifying patients' lifestyle by providing guidance to eating, exercise and healthy practices in general. Inducing conscious health conducts, i.e., understanding why choices have to be made, rather than passive behavioural changes was the goal of our approach. Though eating habits and physical activity were not assessed directly, the results of the CdR-T1DM questionnaire (Table 2 ) suggest that they may have improved. Further support to the notion that group care induced lifestyle modification is provided by the increased levels of HDL cholesterol [38-40], similar to what we observed in T2DM [15-17]. HbA1c was not modified. Possibly, our educational programme focused more on general lifestyle issues and less on such specific skills as carbohydrate counting and fine adjusting of insulin dosage, as practiced by other approaches that improved $\mathrm{HbA1c}$ in the short term, also improving quality of life at 1 year [41].

The additional costs required to improve the quality of life scale would be considered negligible by health economics standards [41]. The choice of this surrogate indicator of cost-utility was made on the basis of our previous experience with T2DM [16] and because of the impossibility of translating our results in quality-adjusted life years [41]. Although the programme in our setting was run jointly by a doctor and a highly experienced psychopaedagogist, personnel costs were calculated on the assumption that, in other clinics, nurses and dieticians would participate in group sessions. Two types of sensitivity analysis were undertaken to further assess the robustness of this cost-effectiveness ratio, showing that: (1) since patients on group care miss much less appointments, differential costs rise if one takes into account the actual attendance rates, and (2) a smaller team composed of well-trained nurses and dieticians could reduce by $34 \%$ the extra cost spent per point gained in quality of life. Either way, these remain appealing economic results.

Finally, patients wholeheartedly endorsed group care. Although both treatments elicited the same degree of perceived satisfaction, group care earned a higher usefulness score and nearly all patients were unwilling to go back to one-toone consultations, the only exception being motivated by timing problems.

It is often stated that new models should be developed to empower patients and build strategies that enable them to cope with chronic diseases. It is also suggested that patient training programmes should routinely aim at enhancing beliefs in self-efficacy, because positive experiences have already been reported in this area [42] and because pure, cognitive knowledge of illnesses and their treatment bears limited significance to everyday life. Our results suggest that group care may represent one such model, in which education merges with clinical care. Though alternative approaches should be negotiated with the patients to achieve more impact on metabolic control, group dynamics and peer identification appear to lead to more active coping behaviour and improved quality of life.

\section{Acknowledgements}

The work described in this paper was supported by funds from the Compagnia di San Paolo, Turin.

\section{References}

[1] The DCCT Research Group. The effect of intensive treatment of diabetes on the development and progression of long-term complications in insulin-dependent diabetes mellitus. N Engl J Med 1993;329:977-86.

[2] American Diabetes Association. Standards of medical care in diabetes. Diabetes Care 2004;27(Suppl.):S15-35.

[3] American Diabetes Association. National standards for diabetes self-management education. Diabetes Care 2003;26(Suppl.):S149-56.

[4] Clement S. Diabetes self-management education. Diabetes Care 1995;18:1204-14.

[5] Funnell MM, Haas LB. National standards for diabetes selfmanagement-education programs. Diabetes Care 1995;18: 100-10.

[6] The DCCT Research Group. Reliability and validity of a diabetes quality-of-life measure for the diabetes control and complications trial (DCCT). Diabetes Care 1988;11:725-32.

[7] Berger $M$, Muhlhauser I. Implementation of intensified insulin therapy: a European perspective. Diabet Med 1995; 12:201-8.

[8] Muhlhauser I, Bott U, Overmann H, Wagener W, Bender R, Jorgens $\mathrm{V}$, et al. Liberalized diet in patients with type 1 diabetes. J Intern Med 1995;237:591-7.

[9] Padgett D, Mumford E, Hyens M, Cartes R. Meta-analysis of the effects of educational and psychosocial interventions on the management of diabetes mellitus. J Clin Epidemiol 1988;41:1007-30.

[10] Brown SA. Studies of educational interventions and outcomes in diabetic adults: a meta-analysis revisited. Patient Educ Couns 1990;16:189-215.

[11] Williams GC, Freedman ZR, Deci EL. Supporting autonomy to motivate patients with diabetes for glucose control. Diabetes Care 1998;21:1644-51.

[12] Anderson RM, Funnel MM, Butler PM, Arnold MS, Fitzgerald JT, Feste C. Patient empowerment: result of a randomised controlled trial. Diabetes Care 1995;18: 943-9.

[13] Bott U, Bott S, Hemmann D, Berger M. Evaluation of a holistic treatment and teaching programme for patients with type 1 diabetes who failed to achieve their therapeutic goals under intensified insulin therapy. Diabet Med 2000;17:635-43. 
[14] Rose M, Fliege H, Hildebrandt M, Schirop T, Klapp BF. The network of psychological variables in patients with diabetes and their importance for quality of life and metabolic control. Diabetes Care 2002;25:25-42.

[15] Trento M, Passera P, Tomalino M, Bajardi M, Pomero F, Allione A, et al. Group visits improve metabolic control in type 2 diabetes: a 2-year follow-up. Diabetes Care 2001; 24:995-1000.

[16] Trento M, Passera P, Bajardi M, Tomalino M, Grassi G, Borgo $\mathrm{E}$, et al. Lifestyle intervention by group care prevents deterioration of type 2 diabetes: a 4-year randomized controlled clinical trial. Diabetologia 2002; 45:1231-9.

[17] Trento $M$, Passera $P$, Borgo E, Tomalino $M$, Bajardi $M$, Cavallo $F$, et al. A 5-year randomized controlled study of learning, problem solving ability and quality of life modifications in people with type 2 diabetes managed by group care. Diabetes Care 2004;27:670-5.

[18] Wdowik MJ, Kendall PA, Ma. Harris. College students with diabetes: using focus group and interviews to determine psychosocial issues and barriers to control. Diabetes Educ 1997;23:558-62.

[19] Hernandez CA, Bradish GI, Rodger NW, Rybansky SI. Selfawareness in diabetes: using body cues, circumstances and strategies. Diabetes Educ 1999;25:576-84.

[20] Jones FC, Broome ME. Focus group with African American adolescents: enhancing recruitment and retention in intervention studies. J Pediatr Nurse 2001;16:88-96.

[21] Marchand C, D'Ivernois JF, Assal JP, Slama G, Hivon R. An analysis, using concept mapping, of diabetic patients' knowledge, before and after patient education. Med Teach 2002;24:90-9.

[22] D'Ivernois JF, Gagnayre R. Apprendre à éduquer le patient, approche pédagogique. Paris: Vigot; 1995.

[23] Whittemore R, Sullivan A, Bak PS. Working within boundaries: a patient-centered approach to lifestyle changes. Diabetes Educ 2003;29:69-74.

[24] Knowles MS. The adult learner. A neglected species. Houston: Gulf Publishing Company; 1997.

[25] Newman P, Peile E. Learning in practice. Valuing learner's experience and supporting further growth: educational models to help experienced adult learners in medicine. Br Med J 2002;325:200-2.

[26] Mannucci E, Mezzani B, Conti A, Rotella CM. Valutazione della qualità della vita nei pazienti adulti diabetici di tipo I. Il Diabete 1994;6:223-8.

[27] Gruppo di Studio per l'Educazione sul Diabete - GISED. Questionario per la valutazione delle conoscenze, dei comportamenti e degli atteggiamenti dei diabetici. II Diabete 1993;5:54-6.

[28] Cronbach LJ. Essentials of psychological testing. 3rd ed. New York: Harpers \& Row; 1970.
[29] Reber A. Dictionary of psychology. London: Penguin; 1985.

[30] Watkins KW, Connell CM, Fitzgerald JT, Klem L, Hichkey T, Ingersoll-Dayton B. Effect of adults' self-regulation of diabetes on quality of life outcomes. Diabetes Care 2000; 23:1511-5.

[31] Glasgow RE, Hampson SE, Strycker LA, Ruggiero L. Personalmodel beliefs and social-environmental barriers related to diabetes self-management. Diabetes Care 1997;20: $556-61$.

[32] Haynes RB. Determinants of compliance: the disease and the mechanics of treatment. In: Haynes RB, Sacker DL, editors. Compliance in health care. Baltimore: John Hopkins University Press; 1979. p. 49-62.

[33] Schechter CB, Walker EA. Improving adherence to diabetes self-management recommendations. Diabetes Spectr 2002;5:170-5.

[34] Rubin RR, Peyrot M. Quality of life and diabetes. Diabetes Metab Res Rev 1999;15:205-18.

[35] Aalto AM, Uutela A, Aro AR. Health related quality of life among insulin-dependent diabetics: disease-related and psychosocial correlates. Patient Educ Couns 1997;30: 215-25.

[36] Klein BE, Klein R, Moss SE. Self-rated health and diabetes of long duration. The Wisconsin epidemiologic study of diabetic retinopathy. Diabetes Care 1998;21: 236-40.

[37] Parkerson GR, Gonnis RT, Broadhead WE, Patrick DL, Taylor TR, Chiu-Kit JT. Disease-specific versus generic measurement of health-related quality of life in insulin-dependent diabetic patients. Med Care 1993; 31:629-39.

[38] Krook A, Holm I, Pettersson S, Wallberg-Henriksson $\mathrm{H}$. Reduction of risk factors following lifestyle modification in subjects with type 2 (non-insulin dependent) diabetes mellitus. Clin Physiol Funct Imaging 2003;23:21-30.

[39] Kohvakka A, Palmroos P, Koivu TA, Roto P, Uitti J, Sillanaukee $P$, et al. Trends in serum cholesterol and lifestyle indicators in Members of the Finnish Parliament. Public Health 2003;117:11-4.

[40] Van Dam RM, Grievink L, Ocke MC, Feskens EJ. Patterns of food consumption and risk factors for cardiovascular disease in the general Dutch population. Am J Clin Nutr 2003;77:1156-63.

[41] DAFNE Study Group. Training in flexible, intensive insulin management to enable dietary freedom in people with type 1 diabetes: dose adjustment for normal eating (Dafne) randomized controlled trial. BMJ 2002;5:326-30.

[42] Laupacis A, Feeny D, Detsky AS, Tugwell PX. How attractive does a new technology have to be to warrant adoption and utilization? Tentative guidelines for using clinical and economic evaluations. CMAJ 1992;146: 473-81.

Available online at www.sciencedirect.com 